\title{
Role of a Pituitary-specific Transcription Factor (Pit-1/GHF-1) or a Closely Related Protein in CAMP Regulation of Human Thyrotropin- $\beta$ Subunit Gene Expression
}

\author{
Hans J. Steinfelder, Sally Radovick, ${ }^{*}$ Melisa A. Mroczynski, ${ }^{\star}$ Peter Hauser, John H. McClaskey, \\ Bruce D. Weintraub, and Fredric E. Wondisford* \\ Molecular, Cellular, and Nutritional Endocrinology Branch, National Institutes of Diabetes and Digestive and Kidney Diseases, \\ Bethesda Maryland, 20892; and *Divisions of Pediatric and Adult Endocrinology, University Hospitals \\ of Cleveland and Case Western Reserve University School of Medicine, Cleveland, Ohio, 44106
}

\begin{abstract}
cAMP regulation of the human thyrotropin- $\beta$ (TSH $\beta$ ) gene cAMP was studied in two heterologous cell lines, a human embryonal kidney cell line (293) and a rat pituitary cell line $\left(\mathbf{G H}_{3}\right)$. In 293 cells, human TSH $\beta$ gene expression was not stimulated by the adenylate cyclase activator forskolin or the CAMP analogue 8-bromo-cAMP (8-Br-cAMP). On the other hand, these agents induced human TSH $\beta$ gene expression 4-12-fold in $\mathbf{G H}_{3}$ cells.
\end{abstract}

Deletion analysis demonstrated that the regions from +3 to $+8 \mathrm{bp}$ and from -128 to $-61 \mathrm{bp}$ were both necessary for cAMP stimulation. The latter region contains three DNA sequences homologous to a pituitary-specific transcription factor, Pit-1/ GHF-1, DNA-binding site. Gel-mobility assays demonstrated that a radiolabeled human TSH $\beta$ probe $(-128$ to $-61 \mathrm{bp})$ formed five specific DNA-protein complexes with mouse thyrotropic tumor (MTT) nuclear extract and two specific complexes with in vitro translated Pit-1/GHF-1. Four of the five MTT complexes and both in vitro Pit-1/GHF-1 complexes were reduced or eliminated by excess of an unlabeled Pit-1/ GHF-1 DNA-binding site from the rat growth hormone gene, but not a mutated version of the same DNA fragment, suggesting that Pit-1/GHF-1 or a closely related thyrotroph protein binds to these DNA sequences. In 293 cells, co-transfection of an expression vector containing the Pit-1/GHF-1 cDNA restored cAMP-responsiveness to the human TSH $\beta$ promoter (5.2- and 6.6-fold maximal stimulation by 8-Br-cAMP and forskolin, respectively) but not the herpes virus thymidine kinase promoter (1.2-fold maximal stimulation by either agent).

Thus we conclude that the human $\operatorname{TSH} \beta$ gene is positively regulated by cAMP in $\mathrm{GH}_{3}$ but not 293 cells. Since the human TSH $\beta$ gene contains at least one high-affinity binding site for Pit-1/GHF-1 in a region necessary for cAMP stimulation and cAMP stimulation could be restored to the human TSH $\beta$ promoter in a previously nonresponsive cell line by the addition of Pit-1/GHF-1, this suggests that Pit-1/GHF-1, or a closely related protein in the thyrotroph, may be a trans-acting factor for

Address correspondence to Fredric E. Wondisford, M.D., Case Western Reserve University, School of Medicine, W147, 2119 Abington Road, Cleveland, OH 44106.

Received for publication 23 January 1991 and in revised form 2 August 1991.

J. Clin. Invest.

(C) The American Society for Clinical Investigation, Inc $0021-9738 / 92 / 02 / 0409 / 11 \$ 2.00$

Volume 89, February 1992, 409-419
cAMP stimulation of the TSH $\beta$ gene. (J. Clin. Invest. 1992. 89:409-419.) Key words: cAMP • Pit-1 • TSH-B • transcription factor $\bullet$ phosphorylation

\section{Introduction}

Thyrotropin (TSH), ${ }^{1}$ like other pituitary glycoprotein hormones, contains two dissimilar noncovalently linked subunits, $\alpha$ and $\beta$. Previous studies revealed a positive regulation of the synthesis and the secretion of TSH not only by its hypothalamic releasing hormone thyrotropin-releasing hormone (TRH) but also by agents acting through the cAMP system (1, 2). A more recent study identified the neuropeptide arginine vasopressin as a possible candidate for a physiological stimulator of TSH secretion acting through the cAMP system (3). In this study the efficiency of arginine vasopressin was comparable to that of TRH, which may act independently from the cAMP system (4). Recent studies with pituitary cells in primary culture suggested that these regulators in some way also affect the production of both subunits at a pretranslational level ( 5 , $6)$. For the expression of the $\alpha$-subunit gene, a stimulatory effect of both mediators has been clearly shown; whereas in the case of the $\beta$-subunit gene, the data are less clear.

TRH has clearly been shown to stimulate the transcriptional activity of $\operatorname{TSH} \beta$ gene, but data on the importance of the cAMP system in regulating $\mathrm{TSH} \beta$ gene expression have been contradictory $(5,6)$. A more recent study by Shupnik et al. (7) confirmed the initial observations of Franklyn et al. (6) that $\mathrm{TSH} \beta$ mRNA levels were increased in rat pituitary cells after treatment with forskolin, an activator of adenylate cyclase. In this study the effect of forskolin, TRH, and the protein kinase $\mathrm{C}$ activator 12-O-tetradecanoyl phorbol-13-acetate (TPA) was investigated (7). Whereas TRH and TPA seemed to confer an induction of rat $\mathrm{TSH} \beta$ expression via regions between -520 and $-204 \mathrm{bp}$, forskolin induction appeared to be primarily mediated by sequences downstream of $-204 \mathrm{bp}$.

Many genes have been shown to be regulated in a positive way by cAMP or agents acting via the cAMP system. In these genes a consensus octamer sequence (CRE) (8-11) that func-

1. Abbreviations used in this paper: $\mathrm{ABCD}$ assay, avidin-biotin DNAbinding assay; AD-5, adenovirus 5; CAT, chloramphenicol acetyltransferase; CRE, cis-acting consensus octamer sequence; CREB, trans-acting octamer factor; MTT, mouse thyrotropic tumor; PCR, polymerase chain reaction; Pit-1/GHF-1, pituitary-specific trans-acting factor; TPA, 12-O-tetradecanoyl phorbol-13-acetate; TRH, thyrotropin-releasing hormone; TSH, thyrotropin-stimulating hormone; TSH $\beta$, TSH $\beta$-subunit. 
tions as a cis-acting enhancer has been identified; and the transacting factor, cAMP response element-binding protein (CREB) that binds to this element has been isolated and characterized $(12,13)$. However, not all the stimulatory effects of cAMP on gene expression can be attributed to this CRE.

Another DNA sequence reported to mediate induction by cAMP is the AP-2 binding site, which has been shown to confer stimulation by protein kinase $A$ as well as protein kinase $C$ (14). In addition, recent data suggest that hormones and neurotransmitters that act through the cAMP system might induce the expression of certain pituitary hormone genes via cell-specific factors (15-17). Stimulatory effects on expression of rat and human GH and rat PRL genes seemed to be mediated by sequences that differ from the classical CRE or the AP-2 sequences (15-17). In most cases the responsive regions are located near the start site of transcription. In all reports cAMP or agents acting via cAMP resulted in an $\sim 10$-fold induction of gene expression. In contrast to CRE-mediated stimulation, these DNA sequences conferred little or no cAMP induction to a heterologous promoter (15).

In this study we investigated the role of the $\mathrm{cAMP} /$ protein kinase A system in the regulation of human $\mathrm{TSH} \beta$ gene expression. Since no permanent TSH-producing cell line was available, the expression of chimeric human $\mathrm{TSH} \beta$-chloramphenicol acetyltransferase (CAT) plasmids was studied in a embryonal human kidney cell line, 293, or a rat pituitary cell line, $\mathrm{GH}_{3}$. In $\mathrm{GH}_{3}$ but not 293 cells, cAMP analogues stimulated CAT activity $\sim 10$-fold from plasmids containing the human $\mathrm{TSH} \beta$ promoter; deletion analysis revealed that only $128 \mathrm{bp}$ of 5 -flanking DNA and $8 \mathrm{bp}$ of the first exon were sufficient for complete cAMP induction. Further studies identified the region from $-128 \mathrm{bp}$ to $-61 \mathrm{bp}$ and +3 to $+8 \mathrm{bp}$ as necessary for the cAMP effect. Since a promoter-specific induction was observed in a pituitary, but not a kidney, cell line, the involvement of a pituitary-specific trans-acting factor was postulated. In co-transfection experiments, an expression vector containing the pituitary-specific trans-acting factor (Pit-1/GHF-1) cDNA restored cAMP induction to the human $\mathrm{TSH} \beta$ promoter in previously non-responsive cell line, 293. Therefore, we suggest that the cell-specific factor Pit-1/GHF-1, or a closely related protein in the thyrotroph, may be involved in cAMP regulation of human $\operatorname{TSH} \beta$ gene expression.

\section{Methods}

Materials. $\left[{ }^{14} \mathrm{C}\right]$ Chloramphenicol $(50-60 \mathrm{mCi} / \mathrm{mmol})$ was obtained from Amersham Corp. (Arlington Heights, IL). Cell culture reagents were purchased from either Advanced Biotechnologies, Inc. (Columbia, MD) or Sigma Chemical Co. (St. Louis, MO). Acetyl CoA (lithium salt), forskolin, and dideoxyforskolin were obtained from Calbiochem-Behring Corp. (San Diego, CA). 8-Bromo-cAMP (8-Br-cAMP) was purchased from Sigma Chemical Co. Human growth hormone immunoassay kits were purchased from Nichols Institute (San Juan Capistrano, CA). Oligodeoxynucleotides were synthesized on a Gene Assembler Plus DNA synthesizer (Pharmacia LKB Biotechnology Inc., Piscataway, NJ) and purified by reverse-phase chromatography.

Plasmid construction. The CAT gene was excised from pSVOCAT (18) using HindIII and BamHI. A -1200 to +7 fragment from the human $\operatorname{TSH} \beta$ gene was excised using
BamHI and BstEII, and a $-128 /+7$ fragment was obtained using EcoRI and BstEII. These fragments were ligated into the BamHI or EcoRI/BamHI site(s) of pUC 19 using a synthetic BstEII/HindIII adaptor (12 bp) or a synthetic BstEII/HindIII fragment containing the entire first exon. Since the adaptor reconstituted the BstEII site, these constructs contained +8 and not +7 bp of the $5^{\prime}$ untranslated region.

Further deletion constructs were obtained using the polymerase chain reaction (PCR). $5^{\prime}$ primers were synthesized with EcoRI or KpnI restriction sites and 3 ' primers with a HindIII sites. The $-128 /+8$ construct was used as a template. The PCR products were ligated to the HindIII site of the CAT coding sequence and the product was inserted into the EcoRI/KpnI and BamHI sites of $\mathrm{pUC18/19}$ vectors. The construction of pTKCAT has been described previously (18). The pTKCAT constructs containing regions of the human $\operatorname{TSH} \beta 5^{\prime}$ flanking region were obtained by inserting PCR fragments containing KpnI and BamHI ends into their respective sites upstream of the herpes simplex thymidine kinase promoter in pTKCAT. p-128( $\Delta 118) /+2 \mathrm{hTSH} \beta C A \mathrm{~T}$ contains a 3-bp mutation of nucleotides -118 to -116 bp (TGA to GTC). p-28/ +8hTSH $\beta$ SVECAT contains the SV40 72-bp repeat enhancer element (gift of K. McKeon, National Institutes of Health, Bethesda, MD) inserted as a BamHI fragment into the parent plasmid, p-28/+8hTSH $\beta$ CAT. All DNA constructs were confirmed using both restriction enzyme analysis as well as DNA sequencing.

To correct for transfection efficiency, cell cultures were transfected with constructs containing the human GH coding sequence by use of either the herpes simplex thymidine kinase promoter (pTKGH) or the mouse metallo-thionein-I promoter (pXGH5). pTKGH was used in studies with treatment periods of $\geq 24 \mathrm{~h}$. pXGH5 was used in the 8-h treatment experiments except where indicated.

Plasmids containing either the gene for a protein kinase A inhibitor protein (pRSVPKI) or a nonfunctional mutant (pRSVPKI mut) were a generous gift of Dr. R. Maurer (University of Iowa, Iowa City, IA). These plasmids are under the control of the Rous sarcoma virus promoter. The Pit-1/GHF-1 plasmid is driven by the cytomegalovirus promoter (pCMVPit1) and was obtained from Dr. L. Staudt (National Institutes of Health). In the respective control plasmid, the coding sequence for Pit-1/GHF-1 was excised with XbaI and BamHI and the ends were made blunt by $\mathrm{S} 1$ nuclease and re-ligated (pCMV).

Cell culture, transfection, and CAT assays. 293 and $\mathrm{GH}_{3}$ cells were cultured in Dulbecco's modified essential medium supplemented with $10 \%$ fetal bovine serum and $4 \mathrm{mM}$ L-glutamine. One day before transfection the cells were trypsinized and plated onto $100-\mathrm{mm}$ dishes. Transfection was performed using the calcium phosphate precipitation method; the precipitate was applied for 16-18 h. Usually $25 \mu \mathrm{g}$ of the human TSH $\beta$ CAT constructs were transfected per dish, and $5 \mu \mathrm{g}$ of a hGH construct was co-transfected to correct for transfection efficiency. The morning after transfection, cells were washed with serum-free medium and shocked for 2 min with $20 \%$ glycerol in Hepes saline ( $\mathrm{pH} 7.5$ ). Thereafter cells were incubated in serum-free Dulbecco's modified essential medium supple-

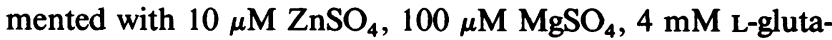
mine, $10 \mu \mathrm{g} / \mathrm{ml}$ insulin, $5 \mu \mathrm{g} / \mathrm{ml}$ transferrin, $5 \mathrm{ng} / \mathrm{ml}$ selenite, and $1 \%$ bovine serum albumin (ITS medium). CAT activity in the cell lysate was determined after the indicated time of treat- 
ment as described (18). The concentration of hGH was determined in the medium and the CAT activity was corrected for transfection efficiency.

Gel-mobility assay. A radiolabeled DNA fragment of the human $\operatorname{TSH} \beta$ gene $(-128$ to $-61 \mathrm{bp})$ and $\mathrm{a}-118$ to $-116-\mathrm{bp}$ mutation of that same fragment (described above) was synthesized using the PCR in the presence of $\left[\alpha-{ }^{32} \mathrm{P}\right] \mathrm{dATP}$ and purified on a $5 \%$ nondenaturing polyacrylamide gel. Each binding reaction was performed in the presence or absence of specific competitor DNA fragments and either $2 \mu \mathrm{g}$ of mouse thyrotropic tumor (MTT) or HeLa cell nuclear extract in $20 \mu \mathrm{l}$ of buffer containing $20 \mathrm{mM}$ Tris pH $8.0,50 \mathrm{mM} \mathrm{KCl}, 10 \%$ glycerol, 1 $\mathrm{mM} \mathrm{MgCl}, 1 \mathrm{mM}$ EDTA, and $4 \mu \mathrm{g}$ of poly (dI.dC) for $30 \mathrm{~min}$ at $25^{\circ} \mathrm{C}$. Nuclear extracts were prepared by the method of Dignam et al. (19) and had a protein concentration of $5-8 \mu \mathrm{g} / \mu \mathrm{l}$ by the Bradford method (Protein Assay Kit; Bio-Rad Laboratories, Richmond, CA). In some experiments, Pit-1/GHF-1 derived from an in vitro transcription-translation system was used in the binding assay. Briefly, the Pit-1/GHF-1 cDNA was cloned in pGEM3Z; capped in vitro Pit-1/GHF-1 was synthesized; and in vitro translation was performed in a rabbit reticulocyte lysate system (18). SDS-polyacrylamide analysis of in vitro synthesized Pit-1/GHF-1 demonstrated a single radiolabeled band of $33 \mathrm{kD}$ (data not shown). $3 \mu \mathrm{l}$ (total translation volume $25 \mu \mathrm{l}$ ) of either an unprogrammed or Pit-1/GHF-1-programmed translation reaction was added to each binding reaction in some experiments. The binding reactions were loaded on a $5 \%$ acrylamide, $0.1 \%$ bisacrylamide gel containing $5 \%$ glycerol, $45 \mathrm{mM}$ Tris, $45 \mathrm{mM}$ borate, and $1 \mathrm{mM}$ EDTA and electrophoresed at $13 \mathrm{~V} / \mathrm{cm}$ for $2 \mathrm{~h}$ at $25^{\circ} \mathrm{C} \mathrm{(20)}$.

DNA-binding assay. The avidin-biotin DNA-binding assay (ABCD assay) was performed using methods previously described (18). Synthetic DNA fragments containing either -122 to $-101 \mathrm{bp},-107$ to $-86 \mathrm{bp},-76$ to $-55 \mathrm{bp}$, or -54 to $-33 \mathrm{bp}$ of the human TSH $\beta$ gene, -89 to -60 of the rat GH gene (rGH-1), -186 to -158 bp of the rat GH gene (rGH/T3), or a region from the long terminal repeat of adenovirus 5 (AD 5) were utilized in this assay. Each DNA fragment contained identical $5^{\prime}$ overhangs (10 base overhangs on each end) that, when repaired by Thermus aquaticus polymerase and biotin 11-dUTP, incorporated 11 biotin residues. Biotinylated DNA concentration was determined using a fluorometric method (Mini Fluorometer, Hoefer Scientific Instruments, San Francisco, CA). Each binding reaction contained $1 \times 10^{4} \mathrm{cpm}$ of radiolabeled Pit-1/GHF-1.

\section{Results}

Localization of CAMP-responsive regions in the human TSH $\beta$ gene. Initial attempts to study the effects of the CAMP/protein kinase A system on human $\operatorname{TSH} \beta$ gene expression in a transient assay were performed in 293 cells, a human embryonal kidney cell line. This cell line has been shown to be capable of producing biologically active human TSH when transfected with the human $\operatorname{TSH} \beta$ gene and a minigene of the common $\alpha$ subunit of pituitary glycoproteins (21). In addition, these cells have been used to study thyroid hormone inhibition of human $\mathrm{TSH} \beta$ gene expression. Transient expression experiments were performed with plasmids containing different lengths of the 5 flanking region coupled to the reporter gene, CAT (18).
However, the effect of cAMP on human TSH $\beta$ gene expression in these cells revealed no significant stimulatory effect by the direct adenylate cyclase activator forskolin at $10 \mu \mathrm{M}$ (1.4fold induction, Fig. 1). This concentration has been shown to maximally activate the cAMP system in other expression systems. Since mRNA studies (6) suggested that there might be a cAMP effect on TSH $\beta$ gene expression in primary pituitary cell cultures, transient transfection experiments were performed in $\mathrm{GH}_{3}$ cells, a rat pituitary cell line. This cell line has been used successfully for studies of the stimulatory effect of TRH on rat (22) and human $\mathrm{TSH} \beta$ gene expression (23). In $\mathrm{GH}_{3}$ cells transfected with a CAT construct containing -1200 to +8 bp of the human TSH $\beta$ gene, forskolin induced CAT activity $\sim 12$-fold (Fig. 1). A second construct containing only -128 to $+8 \mathrm{bp}$ retained full induction by forskolin. As shown below, 2.5 -fold of this induction is due to a nonspecific effect of forskolin on the plasmids utilized in this study.

Since forskolin has been shown to have additional effects besides the activation of adenylate cyclase (24), it was necessary to confirm that elevated cellular cAMP levels mediated the stimulation of human $\mathrm{TSH} \beta$ gene expression in $\mathrm{GH}_{3}$ cells. Therefore, we tested its derivative, dideoxyforskolin, which does not activate adenylate cyclase but shares some of the nonspecific activities of forskolin, for its effect on the expression of chimeric human TSH $\beta$ CAT constructs. Whereas forskolin treatment resulted in the expected 12-fold stimulation of CAT activity, dideoxyforskolin was without any stimulatory effect (data not shown).

Concentration-response and time course of forskolin induction. The concentration-response of stimulation by forskolin was tested with concentrations ranging from 0.32 to $25 \mu \mathrm{M}$ in cells transfected with p- $128 /+8 \mathrm{hTSH} \beta C A T$ construct. At the concentrations tested, the induction by this agent ranged from three to about eightfold. Half-maximal induction was observed at $\sim 0.5 \mu \mathrm{M}$, and maximally effective induction was observed at concentrations of $\geq 3.2 \mu \mathrm{M}$ (data not shown). When cells were transfected with $\mathrm{p}-128 /+8 \mathrm{hTSH} \beta \mathrm{CAT}$ and the expression of CAT activity studied over 8-72 h, the maximal activity (corrected for lysate protein) was observed after $\sim 24 \mathrm{~h}$ in untreated cells. On the other hand, forskolin-treated cells reached their maximal CAT activity after only $8 \mathrm{~h}$. Since basal expression was still increasing up to the 24-h time point, the fold induction after $8 \mathrm{~h}$ of forskolin was larger than that observed at 24-72 h. At the early time points, forskolin induction was larger than 10-fold and dropped to 5-10-fold at the later time points (data not shown).

Further deletional analysis to localize cAMP-responsive regions. When the $\mathrm{p}-128 /+8 \mathrm{hTSH} \beta \mathrm{CAT}$ construct was compared with a construct that contained the complete first untranslated exon of the human $\operatorname{TSH} \beta$ gene (p-128/ $+37 \mathrm{hTSH} \beta \mathrm{CAT}$ ), the induction by either forskolin or the cAMP analogue 8-Br-cAMP was comparable. Forskolin stimulated CAT activity of both constructs 10 -fold, whereas $8-\mathrm{Br}$ cAMP ( $1 \mathrm{mM}$ ) resulted in a 5-6-fold induction (Table I). This suggested that the bases from +9 to +37 of the first exon, which are necessary for the thyroid hormone inhibition of this gene, are not necessary for cAMP stimulation. Further deletion analysis was performed with a p- $28 /+8 \mathrm{hTSH} \beta C A \mathrm{~T}$ plasmid and compared with the induction observed with the p-128/+8hTSH $\beta$ CAT construct. Deletion of $100 \mathrm{bp}$ of $5^{\prime}$ flanking DNA resulted in a $45 \%$ decrease in forskolin induction from 10 - to 


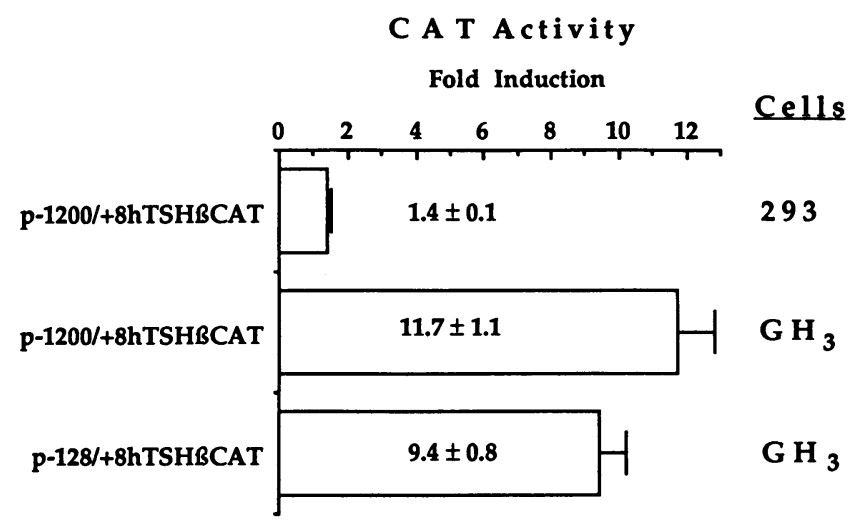

Figure 1. cAMP induction of human TSH $\beta$ gene expression in nonpituitary and pituitary cells. 293 cells or $\mathrm{GH}_{3}$ cells were transfected with the indicated human TSH $\beta$ CAT constructs by the calcium phosphate precipitation method. After an overnight exposure to the precipitate, cell cultures were incubated for $24(293)$ or $72 \mathrm{~h}\left(\mathrm{GH}_{3}\right)$ with forskolin $(10 \mu \mathrm{M})$ in ITS medium. CAT activity in lysates was determined and acetylation corrected for transfection efficiency based on the expression of hGH in the medium. Values are expressed as fold induction of basal activity and represent the mean \pm SEM of three individual transfections.

5.5-fold. With the cAMP analogue 8-Br-cAMP, the loss of stimulation with this deletion was even more pronounced (6.0- vs. $2.4-$ fold, a $60 \%$ reduction). A presumably nonspecific induction of 1.8-fold (8-Br-cAMP) or 2.5-fold (forskolin) was ob-

Table I. Further Deletional Analysis of the Effect of the Protein Kinase A System on the Human TSH $\beta$ Gene Expression

\begin{tabular}{lccc}
\hline \multicolumn{1}{c}{ Plasmid } & $\begin{array}{c}\text { Relative } \\
\text { basal } \\
\text { activity }\end{array}$ & $\begin{array}{c}\text { Forskolin } \\
10 \mu \mathrm{M}\end{array}$ & $\begin{array}{c}\text { 8-Br-cAMP } \\
1 \mathrm{mM}\end{array}$ \\
\hline p-128/+37hTSH $\beta$ CAT & 0.51 & $10.0 \pm 0.6(9)$ & $4.7 \pm 0.2(4)$ \\
p-128/+8hTSH $\beta$ CAT & 0.22 & $10.0 \pm 1.0(5)$ & $6.0 \pm 0.4(6)$ \\
p-28/+8hTSH $\beta$ CAT & 0.69 & $5.5 \pm 0.4(5)^{*, \neq}$ & $2.4 \pm 0.1(7)^{*, \pm}$ \\
p-28/+8hTSH $\beta$ SVECAT & 3.10 & $3.6 \pm 0.6(3)$ & $3.1 \pm 0.4(3)$ \\
pUCCAT & 0.20 & $2.5 \pm 0.2(5)$ & ND \\
pTKCAT & 1.00 & $2.5 \pm 0.2(11)$ & $1.8 \pm 0.2(7)$ \\
p-128/-28TKCAT & 0.83 & $2.2 \pm 0.1(3)$ & $1.7 \pm 0.1(3)$ \\
p-128/+2hTSH $\beta$ CAT & 0.39 & $6.7 \pm 0.7(3)$ & $3.9 \pm 0.4(3)$ \\
p-128( $\Delta 118) /$ & & & \\
$\quad+2 h T S H \beta C A T$ & 0.48 & $3.7 \pm 0.1(3)^{8}$ & $1.8 \pm 0.4(3)^{8}$ \\
p-91/+2hTSH $\beta$ CAT & 0.30 & $3.2 \pm 0.4(3)^{8}$ & $2.3 \pm 0.2(3)^{8}$ \\
p-60/+2hTSH $\beta$ CAT & 0.73 & $2.2 \pm 0.2(3)^{8}$ & $1.9 \pm 0.2(3)^{8}$
\end{tabular}

$\mathrm{GH}_{3}$ cells were transfected with the indicated constructs and incubated with the adenylate cyclase activator forskolin and the cAMP analogue 8-Br-cAMP for $8 \mathrm{~h}$. Thereafter CAT activity was measured in the lysate. Transfection efficiency was monitored by co-transfecting the human growth hormone gene driven by either the herpes thymidine kinase (pTKCAT) or mouse metallothionein-I promoter (pXGH5). Basal CAT activity is relative to the pTKCAT construct, which was used throughout several different experiments.

Values are expressed as mean fold induction of the indicated number of transfections (in parentheses) \pm SEM.

ND, not determined.

* Unpaired $t$ test: $P<0.01,-28 /+8$ vs. $-128 /+8$.

\# Unpaired $t$ test: $P<0.01,-28 /+8$ vs. $-128 /+37$.

Unpaired $t$ test: $P<0.025$, indicated construct vs. $-128 /+2$. served when cell cultures were transfected with a pTKCAT construct or a "promoterless" construct, pUCCAT. To test whether the DNA sequences from -128 to -28 bp were sufficient to confer cAMP responsiveness to a heterologous promoter, this region was inserted upstream of the herpes thymidine kinase promoter in pTKCAT. When tested with either forskolin or 8-Br-cAMP, the induction of this construct was not significantly different from that observed with pTKCAT (2.2- vs. 2.5-fold, forskolin; and 1.7-vs. 1.6-fold, 8-Br-cAMP). Moreover, to determine whether a loss of basal expression in the $\mathrm{p}-28 /+8 \mathrm{hTSH} \beta \mathrm{CAT}$ construct was responsible for a loss in cAMP responsiveness, we inserted a SV40 72-bp repeat enhancer element downstream of the CAT gene in the p-28/ $+8 \mathrm{hTSH} \beta \mathrm{CAT}$ construct, forming p- $28 /+8 \mathrm{hTSH} \beta$ SVECAT. Although basal expression was increased at least fourfold, cAMP responsiveness was not significantly different between these two constructs (Table I).

To define which DNA sequences between -128 and -28 bp mediate the cAMP effect, a new set of plasmids were constructed. The plasmids $\mathrm{p}-128 /+2, \mathrm{p}-128(\Delta 118) /+2, \mathrm{p}-91 /+2$, and $\mathrm{p}-60 /+2 \mathrm{hTSH} \beta \mathrm{CAT}$ were transfected into $\mathrm{GH}_{3}$ cells and the induction of CAT activity by forskolin $(10 \mu \mathrm{M})$ or 8 -BrcAMP $(1 \mathrm{mM})$ was tested. The p-128/+2hTSH $\beta$ CAT construct displayed a $20-30 \%$ lower induction by forskolin or 8Br-cAMP than the p-128/+37 or p- $128 /+8 h$ TSH $\beta C A T$ constructs (Table I), suggesting that DNA sequences near the transcriptional start site of this gene may have some role in mediating these responses. Moreover, the p-128/ $+2 \mathrm{hTSH} \beta \mathrm{CAT}$ construct responded with a 6.7 -fold induction by forskolin, which dropped to 3.2-fold with the p-91/+2hTSH $\beta$ CAT construct and 2.2-fold with the p-60/ $+2 \mathrm{hTSH} \beta \mathrm{CAT}$ construct (Table I). Similar results were obtained with the mediator 8-Br-cAMP. Since the induction of the p-60/+2hTSH $\beta$ CAT construct was similar to that of pTKCAT and pUCCAT, these data indicate that the region from -128 to -61 , and primarily -128 to $-92 \mathrm{bp}$, was responsible for the cAMP induction we observed in the p-128/+2hTSH $\beta$ CAT construct. In support of this hypothesis, a mutation in the $\mathrm{p}-128 /+2 \mathrm{hTSH} \beta C A T$ construct at -118 to $-116 \mathrm{bp}[\mathrm{p}-128(\Delta 118) /+2 \mathrm{hTSH} \beta \mathrm{CAT}]$ also displayed a significant $(50 \%)$ reduction in response to both forskolin and $8-\mathrm{Br}$ cAMP compared with p- $128 /+2 \mathrm{hTSH} \beta C A T$. This 3-bp mutation abolishes one of the three Pit-1/GHF-1 homologous sequences in the human $\operatorname{TSH} \beta$ gene (see Discussion).

Further evidence that protein kinase A mediated the induction of human $\operatorname{TSH} \beta$ expression by forskolin was obtained from two experiments where a Rous sarcoma virus expression vector containing a protein kinase $A$ inhibitory protein $\mathrm{CDNA}$ (pRSVPKI) or a nonfunctional mutant cDNA of the same protein (pRSVPKImut) were cotransfected with p-128/ $+8 \mathrm{hTSH} \beta \mathrm{CAT}$ (Table II) (25). Since the wild-type and mutant inhibitor protein had to be expressed and translated in transfected cell cultures, forskolin was added $4 \mathrm{~h}$ after transfection, and CAT activity was measured after $24 \mathrm{~h}$. In the first experiment utilizing $5 \mu \mathrm{g}$ of pRSVPKI, forskolin stimulation of p- $128 /+8$ hTSH $\beta$ CAT was reduced by $35 \%$ from seven- to fourfold. In the second experiment, $15 \mu \mathrm{g}$ of pRSVPKI was used, which did not significantly reduce basal expression but lowered forskolin induction of p- $128 /+8 \mathrm{hTSH} \beta \mathrm{CAT}$ by $70 \%$ from 7.6- to 2.4-fold. 
Table II. Importance of the Catalytic Subunit of Protein Kinase A in the Induction of Human TSH $\beta$ Gene Expression by Forskolin

\begin{tabular}{lccc}
\hline \multicolumn{1}{c}{ Co-transfection } & $\begin{array}{c}\text { Basal } \\
\text { expression }\end{array}$ & $\begin{array}{c}\text { Fold } \\
\text { stimulation }\end{array}$ & $\begin{array}{c}\text { Inhibition } \\
\text { by PKI }\end{array}$ \\
& & & $\%$ \\
Experiment 1 & & & \\
$\quad 5 \mu$ g pRSVPKI mut & $0.7 \pm 0.01$ & $7.0 \pm 0.3$ & \\
$\quad 5 \mu$ gRSVPKI & $0.6 \pm 0.03$ & $4.0 \pm 0.1$ & 35 \\
Experiment 2 & & & \\
$15 \mu$ g pRSVPKI mut & $2.1 \pm 0.5$ & $7.6 \pm 0.4$ & \\
$15 \mu$ g pRSVPKI & $1.7 \pm .02$ & $2.4 \pm 0.1$ & 70 \\
& & & \\
\hline
\end{tabular}

In addition to the $\mathrm{p}-128 /+8 \mathrm{hTSH} \beta C A \mathrm{~T}$ plasmid, $\mathrm{GH}_{3}$ cells were cotransfected with either the pRSVPKI mut or the pRSVPKI plasmids (see text). In Experiment 1 cells were transfected with $20 \mu \mathrm{g}$ of the CAT and $5 \mu \mathrm{g}$ of the PKI plasmids. In Experiment $210 \mu \mathrm{g}$ of the CAT construct and $15 \mu \mathrm{g}$ of the PKI plasmids were used. Four hours after the glycerol shock, forskolin $(10 \mu \mathrm{M})$ was added for $24 \mathrm{~h}$. The data represent the fold induction of basal activity observed in the presence of forskolin.

Values are expressed as the mean of three individual transfections \pm SEM.

Basal expression is given as percent conversion of ${ }^{14} \mathrm{C}$-chlorampheni$\mathrm{col} / \mathrm{h}$ per $\mathrm{ng} / \mathrm{ml} \mathrm{GH}$ in medium.

Co-transfection of a Pit-1/GHF-1 expression vector restored cAMP responsiveness. Since the data obtained with $\mathrm{GH}_{3}$ cells clearly demonstrated a cAMP effect on human $\operatorname{TSH} \beta$ gene expression, we designed a new set of experiments addressing the lack of response in 293 cells (human embryonal kidney cells). We tested whether forskolin or 8-Br-cAMP would stimu-

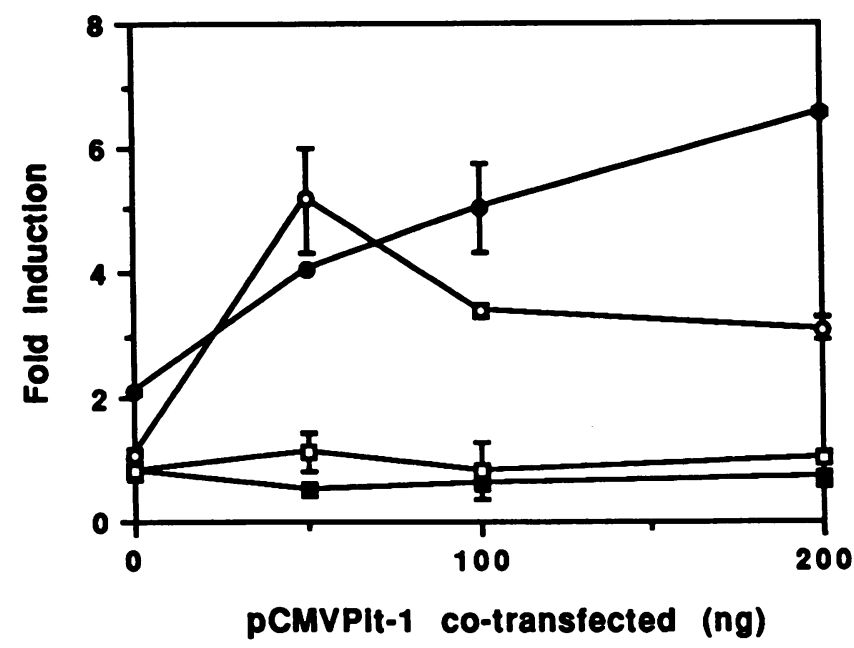

Figure 2. Cotransfection of Pit-1/GHF-1 in 293 cells. The pTKCAT or $\mathrm{p}-128 /+8 \mathrm{hTSH} \beta \mathrm{CAT}$ plasmid was transfected without or with pCMVPit-1 plasmid at the indicated amounts. The data represent the fold induction of basal activity observed in the presence of 8-BrcAMP or forskolin (FSK). Values were obtained from four to six independent transfections and are expressed as the mean \pm SEM. Basal expression was monitored by co-transfecting pTKGH and measuring hGH in the medium. - - - TK, FSK; - - TK, 8 br cAMP; $-\bullet-,-128 /+8$, FSK; - $-,-128 /+8,8$ br cAMP. late expression of either $\mathrm{p}-128 /+8 \mathrm{hTSH} \beta \mathrm{CAT}$ or pTKCAT (Fig. 2). These agents resulted in a maximal stimulation of onefold from pTKCAT and twofold from p-128/ $+8 \mathrm{hTSH} \beta \mathrm{CAT}$. Since both inductions were equal to or less than twofold, these data and the forskolin data presented earlier (Fig. 1) indicate that expression of the herpes thymidine kinase and human $\mathrm{TSH} \beta$ promoters was not specifically regulated by cAMP in 293 cells. This cell line, which lacks Pit-1/ GHF-1 mRNA (PCR analysis, data not shown), was then cotransfected with either an expression vector containing the cytomegalovirus promoter and the pituitary-specific transcription factor, Pit-1/GHF-1 cDNA (pCMVPit-1), or with the parent vector containing the cytomegalovirus promoter but lacking Pit-1/GHF-1 coding sequences (pCMV). Co-transfection of either 50,100 , or $200 \mathrm{ng}$ of the parent vector (pCMV) resulted in a maximal 8-Br-cAMP stimulation of 1.5-fold with the pTKCAT construct and 1.9-fold with the p-128/ $+8 \mathrm{hTSH} \beta \mathrm{CAT}$ construct (data not shown). Moreover, after co-transfection of either 50,100 , or $200 \mathrm{ng}$ of pCMVPit-1, expression of pTKCAT was stimulated a maximum of 1.1-fold by 8 -Br-cAMP and 0.7 -fold by forskolin (Fig. 2). However, co-transfection of either 50,100 , or 200 ng of pCMVPit- 1 stimulated p- $128 /+8 \mathrm{hTSH} \beta C A T$ expression a maximum of 5.2and 6.6-fold by 8-Br-cAMP and forskolin, respectively. This stimulation was similar to that observed in $\mathrm{GH}_{3}$ cells and was definitely more pronounced than that observed in the absence of pCMVPit-1 (less than twofold). Furthermore, co-transfection of either 50,100 , or $200 \mathrm{ng}$ of pCMV or pCMVPit-1 did not significantly increase basal expression of the CAT plasmids or, in data not shown, did not increase expression of another control construct, pRSVLUC (Rous sarcoma virus promoter upstream of the luciferase reporter gene).

Pituitary-specific nuclear proteins interact with the human $T S H \beta$ gene between -128 and $-61 \mathrm{bp}$. To begin to determine what nuclear proteins from the thyrotroph interact with the human $\operatorname{TSH} \beta$ gene between -128 and $-61 \mathrm{bp}$, gel-mobility assays (20) were performed with nuclear extract derived from MTT, a pure population of thyrotrophs; and as a control, nuclear extract derived from a nonpituitary cell line (HeLa cells) was also employed. MTT, but not HeLa, extract yielded five distinct DNA-protein complexes (Fig. $3 A$, lane 2, M1-M5). Each of these complexes proves to be specific since 100 -fold molar excess of the unlabeled fragment $(-128$ to $-61 \mathrm{bp})$ reduced or eliminated these complexes (Fig. $3 \mathrm{~A}$, lane 5).

As shown in Table III, three DNA sequences with high homology to the consensus Pit-1/GHF-1 binding site are found in this region. To test whether these complexes were due to binding of Pit-1/GHF-1, DNA fragments containing either a high-affinity Pit-1/GHF-1 DNA-binding site from the rat GH gene ( $\mathrm{rGH},-93$ to $-66 \mathrm{bp}$ ) or a mutated version of that same fragment (rGH-m) were employed. rGH-m contains a 5-bp mutation of the core Pit-1/GHF-1 DNA binding site present in rGH (rGH, 5' ATTTATTCAT 3'; rGH-m, 5' ATTTAGGTGG $3^{\prime}$ ). Fig. $3 A$ demonstrates that 100 -fold molar excess of rGH (lane 8), but not rGH-m (lane 11), eliminated complexes M3M5 and reduced the intensity of the M2 complex, whereas the M1 complex was eliminated only by -128 to -61 bp fragment. In addition, 10-fold molar excess of rGH (lane 7) reduced in intensity complexes M3-M5. These data suggest that complexes M3-M5 and perhaps M2 are due to an interaction between Pit-1/GHF-1, or a closely related thyrotroph protein, 

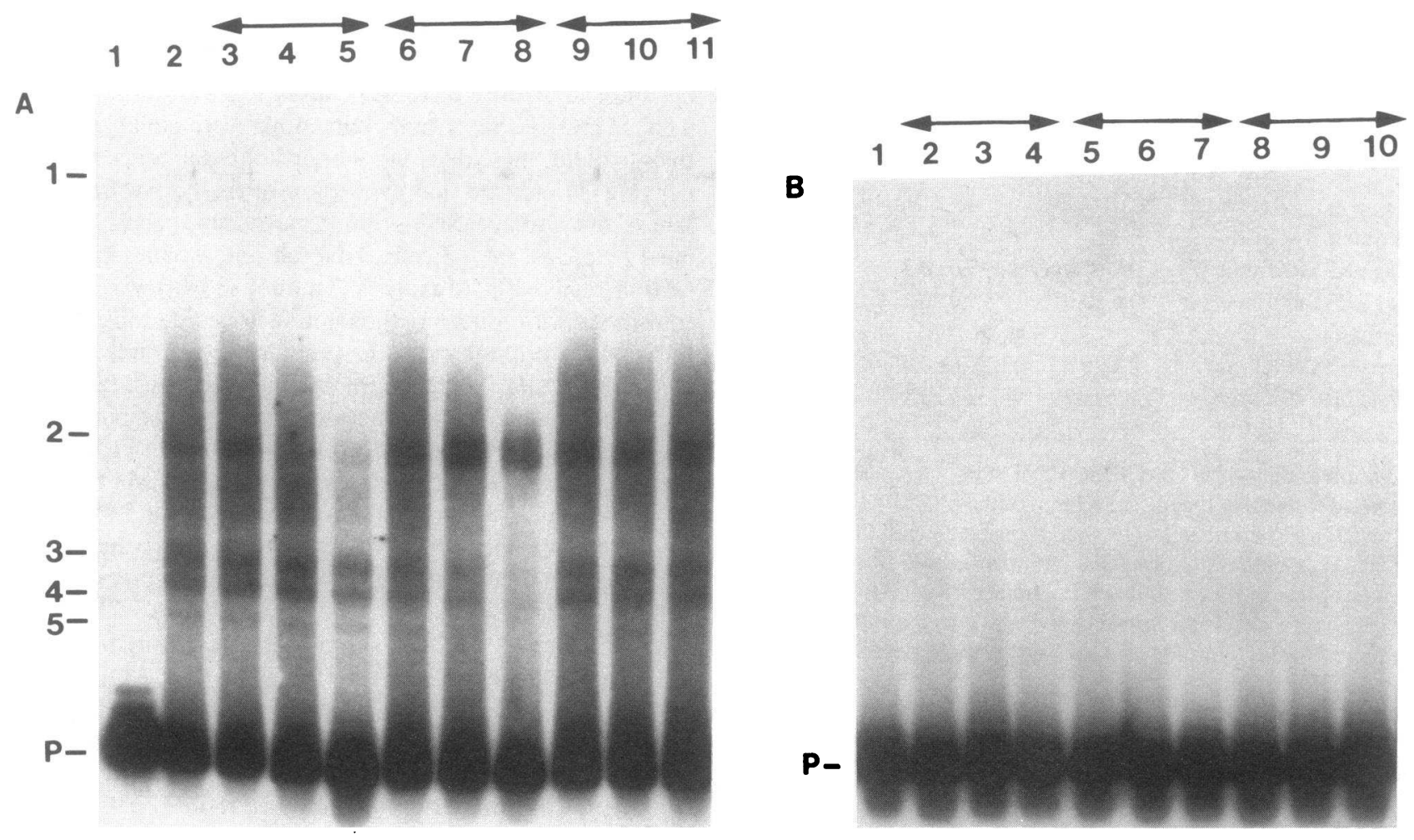

Figure 3. Gel-mobility assay of a region of the human $\operatorname{TSH} \beta$ gene $(-128$ to $-61 \mathrm{bp})$ and various protein extracts. $(A)$ A radiolabeled human TSH $\beta$ probe $(-128$ to $-61 \mathrm{bp}, 1 \mathrm{fmol})$ was incubated in the absence and presence of MTT nuclear extract $(2 \mu \mathrm{g})$. Lane 1 , probe alone; lane 2 , MTT extract alone; lanes 3-5, 1-, 10-, 100-fold molar excess of cold -128 to -61-bp probe; lanes 6-8, 1-, 10-, 100-fold molar of a Pit-1/GHF-1 DNA-binding site (rGH); lanes 9-11, 1-, 10-, 100-fold molar excess of a mutated version of the Pit-1/GHF-1 DNA binding site (rGH-m). (B) An identical experiment was performed with HeLa cell nuclear extract. Lane 1, HeLa cell extract alone; lanes 2-4, 1-, 10-, 100-fold molar excess of cold -128 to -61-bp probe; lanes 5-7, 1-, 10-, 100-fold molar of rGH; lanes 8-10, 1-, 10-, 100-fold molar excess of rGH-m.

and the radiolabeled -128 to -61 -bp human TSH $\beta$ probe, whereas the M1 complex is due to an interaction with an unrelated thyrotroph protein and the radiolabeled probe.

Fig. $3 \mathrm{~B}$ demonstrates that protein-DNA complexes were not detected when an equivalent amount of HeLa cell extract $(2 \mu \mathrm{g})$ was utilized. In data not shown, as much as $10 \mu \mathrm{g}$ of HeLa cell extract did not result in discernible protein-DNA

Table III. Possible Pit-1 Recognition Sequences in the 5' Flanking Region of the Human TSH $\beta$ Gene

\begin{tabular}{|c|c|c|}
\hline $\begin{array}{l}\text { Consensus } \\
\text { Core }\end{array}$ & 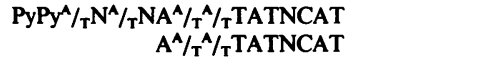 & \\
\hline Boundary & Sequence & Match \\
\hline$-104 /-119$ & 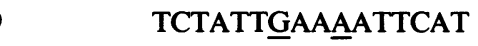 & $14 / 16$ \\
\hline$-89 /-104$ & CTTATCTGAAAAGCAT & $12 / 16$ \\
\hline$-58 /-73$ & GTTTATACAATTGCAT & $12 / 16$ \\
\hline
\end{tabular}

The region from -128 to +8 bp of the human $\operatorname{TSH} \beta$ gene was screened for homologies to the consensus binding sequence of Pit-1/ GHF-1 as characterized by Nelson et al. (29). DNA sequences are from the anticoding strand of the human TSH $\beta$ gene. Underlined nucleotides differ from the consensus sequence. These sequences are identical to those in the rat and mouse $\operatorname{TSH} \beta$ gene, except for the nucleotide at $-65 \mathrm{bp}$, which is a deoxythymidine in the rat and mouse anticoding strand. complexes. However, this extract was shown to form specific complexes with a DNA probe containing a CRE (not shown). Thus, the protein-DNA complexes formed by MTT extract and human TSH $\beta$ probe are unlikely to be due to binding of general transcription factors.

Fig. $4 A$ demonstrates that in vitro synthesized Pit-1/GHF1 formed two specific complexes, $\mathrm{P} 2$ and $\mathrm{P} 3$, with the radiolabeled wild type -128 to -61 -bp probe (Fig. $4 \mathrm{~A}$, lane 3 ) that were not detected in an identical unprogrammed in vitro translation reaction (Fig. $4 \mathrm{~A}$, lanes 2 and 13). Complex P1 was detected in both unprogrammed and Pit-1/GHF-1-programmed in vitro translation reactions and thus represents a protein-DNA complex unrelated to Pit-1/GHF-1. The competitor DNA fragment $\mathrm{rGH}$, but not $\mathrm{rGH}-\mathrm{m}$, eliminated both the $\mathrm{P} 2$ and $\mathrm{P} 3$ complexes (compare lanes 9 and 12). Since in vitro translation products are devoid of endogenous nuclear proteins, these data suggest that complexes $\mathbf{P} 2$ and $\mathrm{P} 3$ may represent binding of two or more and one Pit-1 molecules to the -128 to -61 probe, respectively. Moreover, the relative mobility of the P2 and P3 complexes are similar, although not identical, to that of the M2 and M5 complexes generated by the MTT extract (Fig. $4 A$, lanes 3 and 14, respectively).

Fig. $4 B$ demonstrates that a mutation of bases -118 to $-116 \mathrm{bp}$ in $\mathrm{a}-128$ to $-61 \mathrm{bp}$ probe (MUT) eliminated the specific $\mathrm{P} 2$ and $\mathrm{P} 3$ complexes formed with in vitro translated Pit-1/GHF-1 but not the P1 complex (compared lane 3, Fig. 4 $A$ with lane 3, Fig. $4 B$ ). Moreover, the complexes formed be- 
W T

A

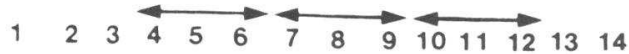

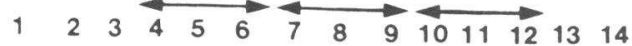

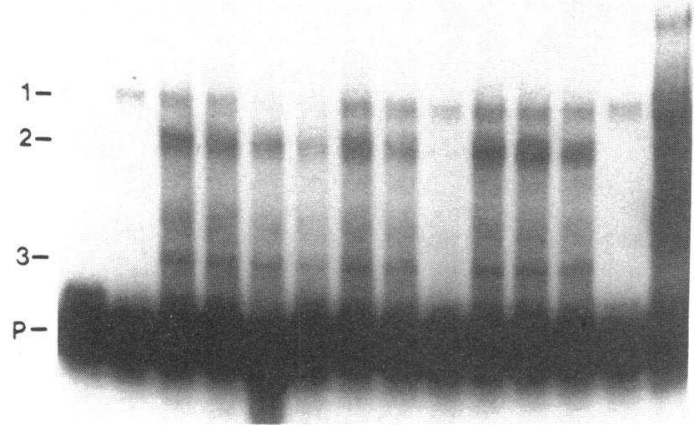

B
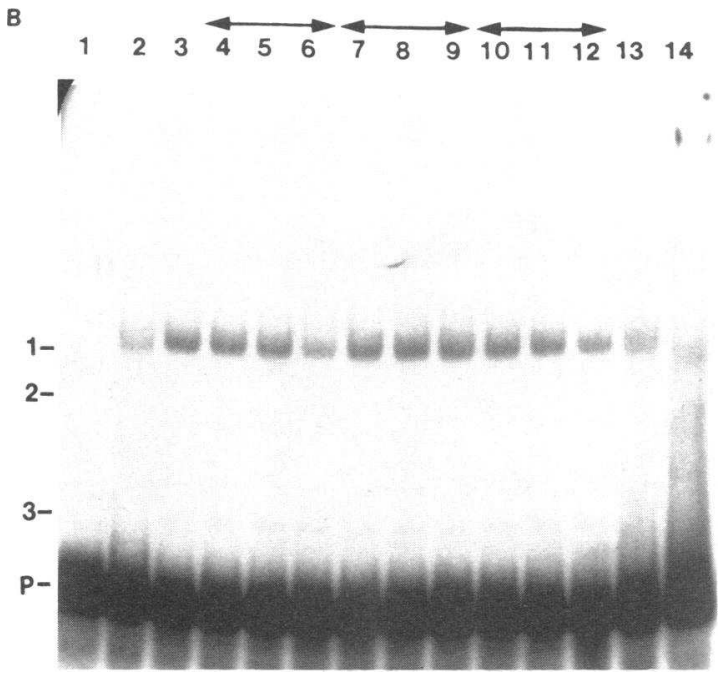

Figure 4. Gel-mobility assay of a region of a wild type ( -128 to $-61 \mathrm{bp})$ and a mutant human TSH $\beta$ probe $(-128$ to -61 bp $\Delta 118-116)$ and in vitro translation extracts. $(A)$ Unprogrammed and Pit-1/GHF-1 mRNA programmed in vitro translation products were utilized in this gel-mobility assay with the wild type $(W T)$ radiolabeled probe. Lane 1 , probe alone; lanes 2 and 13 , each lane contains $3 \mu$ lof an unprogrammed in vitro translation reaction; lanes 3-12, each lane contains $3 \mu$ of a Pit-1/GHF-1 mRNA-programmed in vitro translation reaction; lane 3, no specific competitor; lanes 4-6, 1-, 10-, 100-fold molar excess of cold -128 to -61-bp probe; lanes 7-9, 1-, 10-, 100-fold molar of rGH; lanes $10-12,1-, 10-, 100$-fold molar excess of rGH-m; lane 14, MTT extract without specific competitor. $(B)$ An identical analysis was done with the mutant probe $(M U T)$. Specific protein-DNA complexes are indicated by the numbers to the left of the autoradiographs. $P$ is the migration position of the free radiolabeled human TSH $\beta$ probe, -128 to $-61 \mathrm{bp}$.

tween this mutant probe and the MTT extract were significantly diminished (compare lane 14, Fig. $4 \mathrm{~A}$ with lane 14 , Fig. $4 B$ ). Thus, a mutation that significantly reduced cAMP induction of the human $\mathrm{TSH} \beta$ promoter also abolished or reduced binding of Pit-1/GHF-1 and related MTT proteins to $\mathrm{a}-128$ to -61 human $\mathrm{TSH} \beta$ probe.

5'-flanking region of the human TSH $\beta$ gene contains a highaffinity Pit-1/GHF-1 binding site. Since co-transfection of a Pit-1/GHF-1 expression vector into 293 cells restored cAMP induction to a contruct containing -128 to +8 bp of the human $\operatorname{TSH} \beta$ promoter, the ABCD assay was used to determine whether Pit-1/GHF-1 binds to this region with high affinity. Four biotinylated human $\mathrm{TSH} \beta$ DNA fragments $(-122$ to $-101 \mathrm{bp}$, also referred to as $\mathrm{hTSH} \beta-1 ;-107$ to $-86 \mathrm{bp} ;-76$ to $-55 \mathrm{bp}$; and -54 to $-33 \mathrm{bp}$ ) were employed in the ABCD assay. The first three DNA fragments encompass one of the three DNA sequences with homology to the Pit-1/GHF-1 DNA-binding site (see Table III). As negative controls, a thyroid hormone stimulatory element from the rat $\mathrm{GH}$ gene $(-186$ to $-158 \mathrm{bp}, \mathrm{rGH} / \mathrm{T} 3)$ and a region from the long terminal repeat of AD 5 were used. Fig. $5 A$ demonstrates that hTSH $\beta-122 /-101$ bound significantly more ${ }^{35}$ S-labeled Pit-1/ GHF- 1 than the negative control fragments $\mathrm{rGH} / \mathrm{T} 3$ and AD 5. $\mathrm{hTSH} \beta-107 /-86$ and hTSH $\beta-76 /-55$, the two sites less homolgous to the Pit-1/GHF-1 DNA binding site, bound threefold less ${ }^{35}$ S-labeled Pit-1/GHF-1 than $\mathrm{hTSH} \beta-122 /-101$ but still significantly more than the negative control fragments. ${ }^{35} \mathrm{~S}$-labeled Pit-1/GHF-1 binding to hTSH $\beta-54 /-33$, which does not contain sequence homology to the Pit-1/GHF-1 DNA binding site, was not significantly different from its binding to the negative control fragments.
To determine the affinity of an interaction between ${ }^{35} \mathrm{~S}$-labeled Pit-1/GHF-1 and hTSH $\beta-122 /-101$ (hTSH $\beta-1$ ), the ABCD assay was again used. As a positive control, a biotinylated DNA fragment from the rat GH gene containing a highaffinity Pit-1/GHF-1 binding site ( -89 to $-60 \mathrm{bp}$, rGH-1) was utilized; and as a negative control, AD 5 was employed.

Fig. $5 \mathrm{~B}$ demonstrates that increasing amounts of both the hTSH $\beta-1$ and rGH-1 DNA fragments bound significantly more ${ }^{35}$ S-labeled Pit-1/GHF-1 than the negative control fragment, AD 5. The affinity of the hTSH $\beta-1$ and rGH-1 DNAbinding sites for Pit-1/GHF-1 was calculated from this data using Scatchard analysis. The $K_{\mathrm{d}}$ of the $\mathrm{rGH}-1$ site for Pit-1/ GHF-1 $(2.9 \mathrm{nM})$ is similar to that reported by Ingraham et al. $(0.8 \mathrm{nM}$, reference 26$)$. The hTSH $\beta-1$ fragment exhibited a 2.6-fold lower affinity for Pit-1/GHF-1 with a $K_{d}$ of $7.5 \mathrm{nM}$.

\section{Discussion}

The use of the pituitary cell line $\mathrm{GH}_{3}$ allowed us to study the involvement of the cAMP or protein kinase $A$ in the regulation of the expression of the human $\operatorname{TSH} \beta$ gene. In this system a 10 -fold induction by forskolin and a 5-6-fold induction by 8 -Br-cAMP was conserved in a plasmid containing only $128 \mathrm{bp}$ of the promoter region and $8 \mathrm{bp}$ of the first untranslated exon of the gene. No promoter-specific induction by forskolin was observed in the non-pituitary cell line 293 . These data are in good agreement with observations of cell-specific and cAMPregulated expression of the rat PRL and rat and human GH genes in this or related cell lines (15-17). In all these studies an $\sim 10$-fold induction of promoter activity by forskolin was observed. Similar to the data on the human $\operatorname{TSH} \beta$ gene in this 


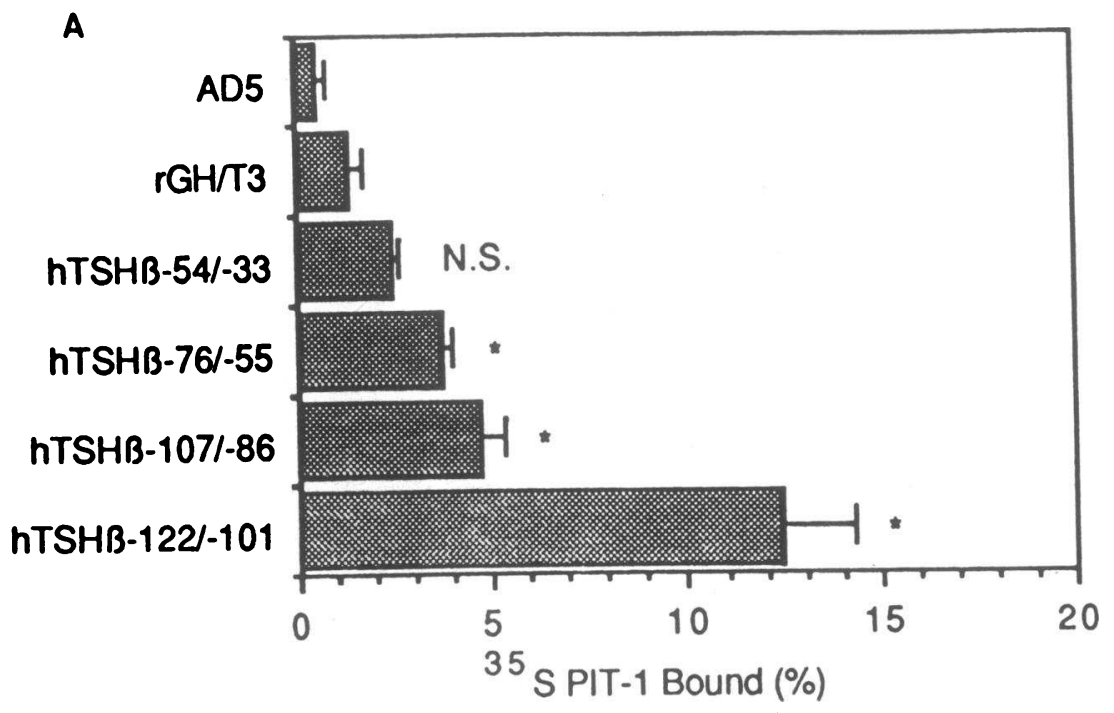

$-\mathrm{rGH}-1$

B

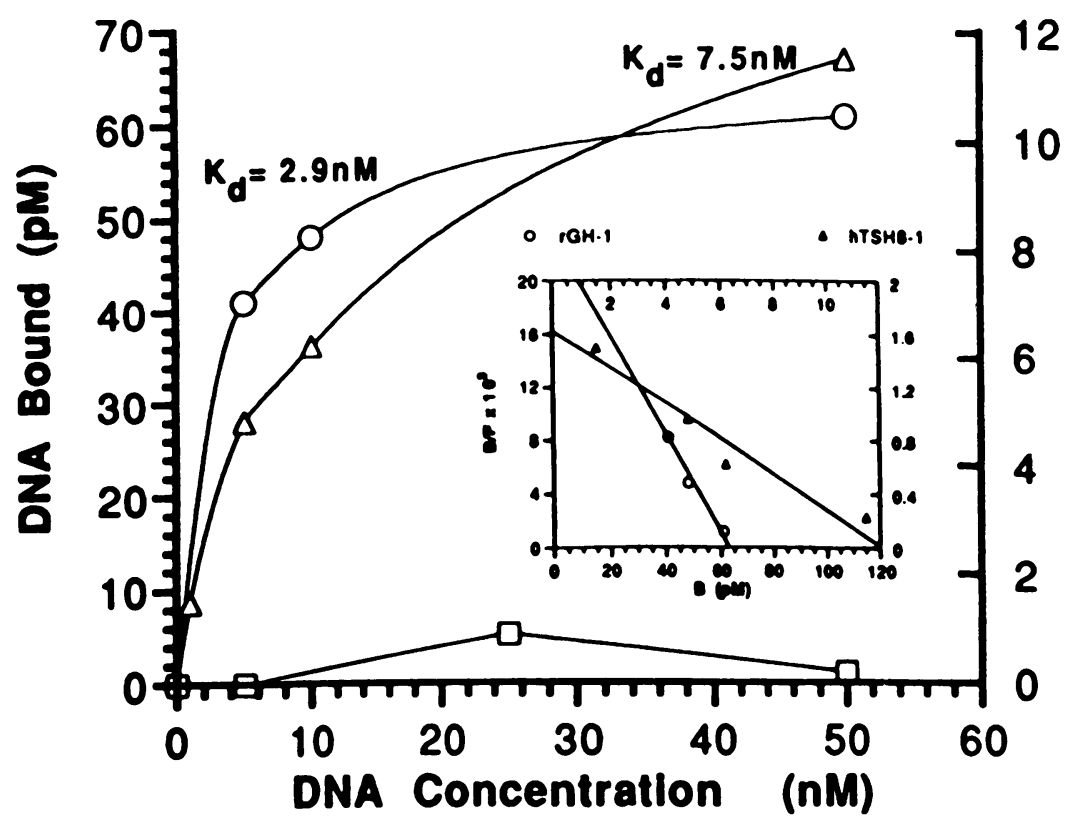

Figure 5. (A) An ABCD assay using ${ }^{35}$ S-labeled Pit-1/GHF-1 and biotinylated DNA fragments from the hu$\operatorname{man} \operatorname{TSH} \beta$, rat $\mathrm{GH}$, and the AD 5 gene. Human TSH $\beta$ gene fragments as indicated were used, as well as negative control fragments from a thyroid hormone stimulatory element in the rat GH gene ( $\mathrm{GGH} / \mathrm{T} 3$ ) and a region from the long terminal repeat of $A D 5$. Data points are the mean of triplicate determination \pm SEM. Unpaired Student's $t$ test: $P<0.005$, indicated fragment vs. rGH/T3 or AD 5; NS, not significantly different from $\mathrm{rGH} / \mathrm{T} 3$ or AD 5. (B) An ABCD assay using ${ }^{35}$ S-labeled Pit-1/GHF-1 and biotinylated DNA fragments from the rat GH and human TSH $\beta$ and AD 5 genes. Biotinylated DNA fragments that contain either -89 to $-60 \mathrm{bp}$ of the rat GH gene (rGH-1), -122 to -101 of the human $\operatorname{TSH} \beta$ gene (hTSH $\beta-1)$, or a region from the long terminal repeat of AD 5. Biotinylated DNA bound to ${ }^{35} \mathrm{~S}$-labeled Pit-1/GHF-1 picomolar vs. the biotinylated DNA concentration nanomolar is illustrated. This graph represents results from two binding experiments, each performed in duplicate. Each data point is the mean of duplicate determinations. $K_{d}$ for the rGH- 1 and $h$ TSH $\beta-1$ DNA fragments was determined by Scatchard analysis (see inset). paper, the induction was conserved to a short region of the promoter, usually $130-100$ bp upstream from the start site of transcription. However, when the $5^{\prime}$ flanking region of the human $\operatorname{TSH} \beta$ gene was reduced from -128 to -28 bp (p-28/+8hTSH $\beta$ CAT), the induction by forskolin or other agents activating protein kinase $A$ was reduced by $\sim 60 \%$. This reduction in cAMP responsiveness was not simply due to a decrease in basal expression, since we were unable to restore cAMP induction to a $-28 /+8 \mathrm{hTSH} \beta$ promoter fragment after increasing basal expression with an SV40 enhancer element (p-28/+8hTSH $\beta$ SVECAT. Further analysis revealed that the regions from -128 to -61 and +3 to +8 bp were both important for this cAMP induction (Table I and Fig. 6).

The 1.8-2.5-fold effect of cAMP on the expression of the control plasmids, pTKCAT and pUCCAT, is similar to the effect of cAMP on CAT expression from other promoters, such as the Rous sarcoma virus $(11,27)$, mouse mammary tumor virus (15), and herpes simplex thymidine kinase (27). This may represent an effect on general transcription factors or may be due to a higher viability of transfected cells in the presence of the CAMP analogues. Since the CAT-containing sequences in our human TSH $\beta$ CAT plasmids are virtually identical to those 


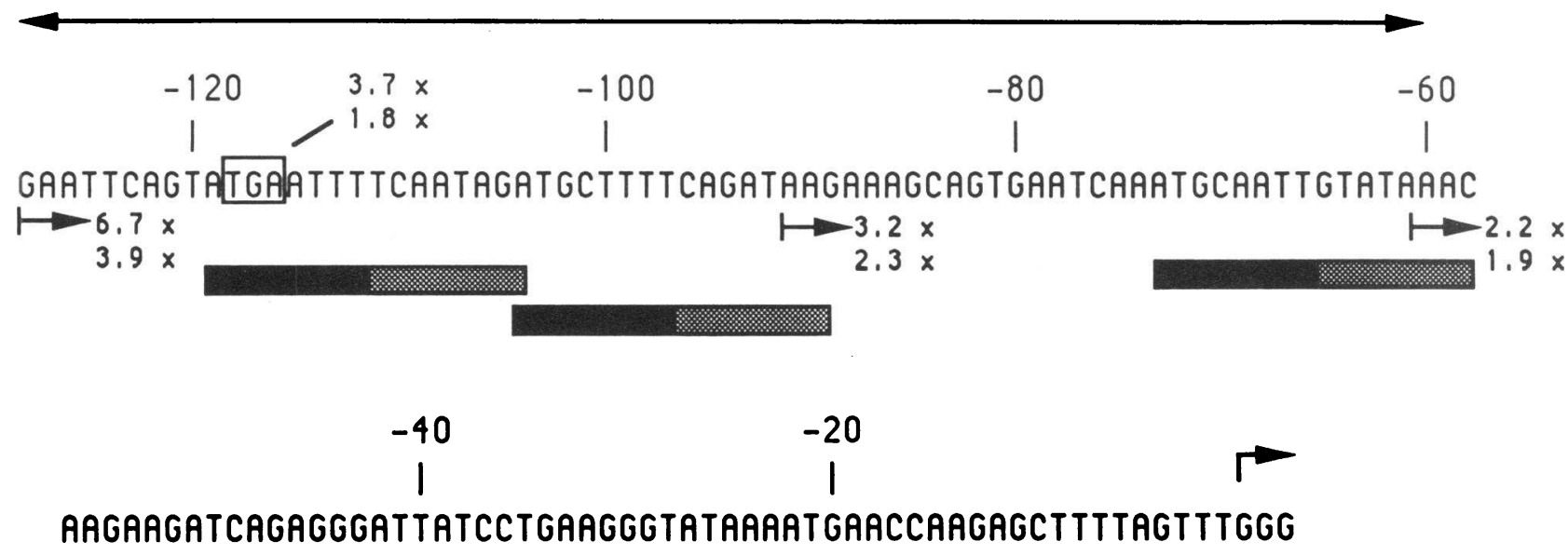

Figure 6. Summary of functional and structural data of cAMP regulation of human TSH $\beta$ gene expression. The $5^{\prime}$ flanking region of the human $\mathrm{TSH} \beta$ gene is illustrated (numbering relative to the start of transcription shown by the $\vec{r}$ ). Fold stimulation by either forskolin (top) or 8-Br-cAMP (bottom) of a construct containing the corresponding 5 ' end point and +2 bp of the human TSH $\beta$ gene is displayed. Fold stimulation by either forskolin or 8-Br-cAMP of a -128 to +2 -bp human $\mathrm{TSH} \beta$ gene construct containing a mutation of nucleotides -118 to -116 bp (boxed nucleotides, TGA to GTC) is also shown. Three DNA sequence homologies to the consensus Pit-1/GHF-1 DNA-binding site are indicated by the boxed regions below the $5^{\prime}$ flanking sequences; the core sequence homology of $8 \mathrm{bp}$ is indicated by a black box within the consensus sequence. The probe utilized in gel-mobility assays is illustrated by the double arrowhead line.

of the control CAT plasmids, we conclude that the much greater effect of cAMP on human TSH $\beta$ CAT plasmids is most likely due to a selective effect on transcription. The conclusion that 2-2.5-fold inductions might be considered as a nonspecific action of elevated cAMP levels is further supported by the observations that even high concentrations of a co-transfected protein kinase A inhibitor protein gene reduced forskolin induction to approximately twofold.

The importance of cAMP as the mediator of forskolin-stimulated CAT activity from the human $\operatorname{TSH} \beta$ plasmids was addressed in two ways. First, the cAMP analogue, 8-Br-cAMP, displayed the same induction pattern on various chimeric human TSH $\beta$ CAT plasmids as forskolin. The maximal induction with this agent was about one half of that observed with forskolin. Second, co-transfection of a gene encoding a heat-stable protein kinase $\mathrm{A}$ inhibitor protein reduced forskolin induction by $70 \%$ without a significant effect on basal expression. In addition, this observation shows the importance of the catalytic subunit of protein kinase $A$ for the positive regulation of human TSH $\beta$ gene expression by cAMP.

Interestingly, human TSH $\beta$ DNA sequences from -128 to $-61 \mathrm{bp}$, which are important for cAMP induction, contain three homologous sequences (Table III) to the consensus DNA-binding site of Pit-1/GHF-1 (28, 29), suggesting that Pit1/GHF-1 might be involved in the induction of human TSH $\beta$ gene expression by cAMP. In support of this hypothesis, $\sim 50 \%$ of pituitary thyrotrophs contain Pit-1/GHF-1 (30); and recently, a central role for Pit-1/GHF-1 in thyrotroph cellular regulation and TSH secretion was shown by $\mathrm{Li}$ et al. (31) in several mice strains containing mutations of the Pit-1/GHF-1 gene.

Gel-mobility assays of a radiolabeled human TSH $\beta$ probe from -128 to -61 bp indicate that Pit-1/GHF-1, or a closely related thyrotroph protein, interacts with this region. Moreover, a DNA fragment from this region, containing -122 to -101 bp of the human TSH $\beta$ gene, bound ${ }^{35}$ S-labeled Pit-1/ GHF-1 with high affinity, although the affinity of this interac- tion was lower than that observed with the high-affinity binding site in the rat GH gene ( $K_{\mathrm{d}}=7.5$ vs. $2.9 \mathrm{nM}$, respectively). The apparent differences in mobilities between protein-DNA complexes generated by MTT nuclear extract and in vitro translated Pit-1/GHF-1 may represent differences between authentic Pit-1/GHF-1 in the thyrotroph and in vitro synthesized Pit-1/GHF-1. Moreover, post-translational modifications of Pit-1/GHF-1 in the thyrotroph could also explain the differences in mobilities. Alternatively, the protein-DNA complexes generated by MTT extract may contain a nuclear protein closely related but not identical to Pit-1/GHF-1. Recently, Alexander et al. (32) have described a lactotroph-specific transcription factor that binds to corresponding regions in the murine TSH $\beta$ gene. This larger molecular weight protein is related to Pit-1/GHF-1 and migrates as a triplet between 36 and 40 $\mathrm{kD}$. Thus, the apparent decrease in mobility between proteinDNA complexes generated by MTT nuclear extract and in vitro translated Pit-1/GHF-1 could also be explained by an interaction between the radiolabeled probe and lactotroph-specific transcription factor or another putative thyrotroph-specific factor.

Co-transfection studies using an expression vector containing the Pit-1/GHF-1 cDNA also support the hypothesis that this or a related transcription factor is necessary for cAMP stimulation of the human $\mathrm{TSH} \beta$ gene. In a previously unresponsive cell line, 293, co-transfection of pCMVPit-1 restored cAMP stimulation to the human $\operatorname{TSH} \beta$ gene. Since expression of Pit-1/GHF-1 is under control of a viral promoter, these data suggest that cAMP may directly activate Pit- $1 /$ GHF-1 via phosphorylation, resulting in an increase in human $\mathrm{TSH} \beta$ gene expression. Recently, in fact, Kapiloff et al. (33) have shown that Pit-1/GHF-1 is phosphorylated by cAMP analogues in vitro and in vivo at two sites and that phosphorylation at one site alters binding of Pit-1/GHF-1 to various DNA elements. Importantly, though, it has also been recently shown that the expression of the Pit-1/GHF-1 gene is induced approximately threefold by cAMP (34), and two CREB binding sites were 
found in the $5^{\prime}$ flanking region of the Pit-1/GHF-1 gene. Therefore, cAMP might also raise intracellular levels of Pit-1/GHF-1 via phosphorylation of CREB and activation of the Pit-1/ GHF-1 gene, as has been shown for other cAMP-regulated genes (35). This induction of Pit-1/GHF-1 could then stimulate the expression of the human $\operatorname{TSH} \beta$ gene via an indirect mechanism.

In the case of the common glycoprotein $\alpha$-subunit gene, cAMP activates transcription via interaction of CREB with a CRE in the $5^{\prime}$ flanking region $(8,9)$. The mechanism of this induction is considered to be direct via preexisting proteins since inhibition of protein synthesis did not affect cAMP induction. On the other hand, data on the regulation of the expression of the hCG $\beta$ subunit are less clear. Like the human $\mathrm{TSH} \beta$ gene, this gene does not contain a classical CRE. Differences in the kinetics of cAMP stimulation of $\alpha$ and CG $\beta$ transcription rates (36) and activation of transiently expressed fusion genes (37) have led to the hypothesis that, in contrast to the $\alpha$ gene, the stimulation of $\mathrm{CG} \beta$ transcription by cAMP occurs indirectly. Recent data on cAMP stimulation of $\mathrm{CG} \beta$ expression are still inconclusive. In BeWo cells, protein synthesis inhibitors eliminated the stimulatory effect of cAMP on $\mathrm{hCG} \beta$ transcription, thereby suggesting an indirect effect of the cyclic nucleotide (38). In contrast, in JEG-3 cells the stimulation of both $\alpha$ and $\mathrm{CG} \beta$ gene transcription seemed to be mediated by stable proteins (39); therefore, cAMP was thought to directly stimulate induction of both subunit genes. Future studies of cAMP stimulation of human TSH $\beta$ gene expression will explore whether this stimulation is via a direct mechanism, indirect mechanism, or a combination of both mechanisms.

In conclusion, the expression of chimeric human TSH $\beta C A T$ plasmids in the pituitary $\mathrm{GH}_{3}$ cells is positively regulated by the CAMP and is the result of activation of the catalytic subunit of the protein kinase A. Regions mediating the major portion of this induction were localized between -128 and -91 bp and +3 to +8 bp. The involvement of Pit-1/GHF-1, or a closely related protein in the thyrotroph, in the stimulation of human $\operatorname{TSH} \beta$ gene expression by cAMP is suggested.

\section{Acknowledgments}

This work was supported by grants from the Deutsche Forschungs-gemeinschaft to $\mathrm{H}$. J. Steinfelder and the National Institutes of Health (DK43653-01) to F. E. Wondisford.

\section{References}

1. Vale, W., G. Grant, M. Amoss, R. Blackwell, and R. Guillemin. 1972. Culture of enzymatically dispersed anterior pituitary cells: functional validation of a method. Endocrinology. 91:562-572.

2. Nakano, H., C. P. Fawcett, and S. M. McCann. 1976. Enzymatic dissociation and short-term culture of isolated rat anterior pituitary cells for studies on the control of hormone secretion. Endocrinology. 98:278-288.

3. Lumpkin, M. D., W. K. Samson, and S. M. McCann. 1987. Arginine vasopressin as a thyrotropin-releasing hormone. Science (Wash. DC). 235:10701073.

4. Gershengorn, M. C., M. J. Rebecchi, E. Geras, and C. O. Arevalo. 1980. Thyrotropin-releasing hormone (TRH) action in mouse thyrotropic tumor cells in culture: evidence against a role for $3^{\prime}, 5^{\prime}$ monophosphate as a mediator of TRHstimulated thyrotropin release. Endocrinology. 107:665-670.

5. Shupnik, M. A., S. L. Greenspan, and E. C. Ridgway. 1986. Transcriptional regulation of thyrotropin subunit genes by thyrotropin-releasing hormone and dopamine in pituitary cell culture. J. Biol. Chem. 261:981-987.

6. Franklyn, J. A., M. Wilson, J. R. Davis, K. Ramsden, K. Docherty, and
M. C. Sheppard. 1986. Demonstration of thyrotropin $\beta$-subunit messenger RNA in rat pituitary cells in primary culture-evidence for regulation by thyrotropinreleasing hormone and forskolin. J. Endocrinol. 111:R1-R2.

7. Shupnik, M. A., B. A. Rosenzweig, and M. O. Showers. 1990. Interactions of thyrotropin-releasing hormone, phorbol ester, and forskolin-sensitive regions of the rat thyrotropin- $\beta$ gene. Mol. Endocrinol. 4:829-836.

8. Deutsch, P. J., L. J. Jameson, and J. F. Habener. 1987. Cyclic AMP responsiveness of human gonadotropin- $\alpha$ gene transcription is directed by a repeated 18-base pair enhancer. J. Biol. Chem. 262:12169-12714.

9. Silver, B. J., J. A. Bokar, J. B. Virgin, E. A. Vallen, A. Milsted, and J. H. Nilson. 1987. Cyclic AMP regulation of the human glycoprotein hormone $\alpha$-subunit gene is mediated by an 18-base-pair element. Proc. Natl. Acad. Sci. USA. $84: 2198-2202$.

10. Montminy, M. R., K. A. Sevarino, J. A. Wagner, G. Mandel, and R. H. Goodman. 1986. Identification of a cyclic-AMP-responsive element within the rat somatostatin gene. Proc. Natl. Acad. Sci. USA. 83:6682-6686.

11. Tsukada, T., S. J. Fink, G. Mandel, and R. H. Goodman. 1987. Identification of a region in the human vasoactive intestinal peptide gene responsible for regulation by cyclic AMP. J. Biol. Chem. 262:8743-8747.

12. Montminy, M. R., and L. M. Bilezikjian. 1987. Binding of a nuclear protein to the cyclic-AMP response element of the somatostatin gene. Nature (Lond.). 328:175-178.

13. Hoeffler, J. P., T. E. Meyer, Y. Yun, J. L. Jameson, and J. F. Habener. 1988. Cyclic AMP-responsive DNA-binding protein: structure based on a cloned placental cDNA. Science (Wash. DC). 242:1430-1433.

14. Imagawa, M., R. Chiu, M. Karin. 1987. Transcription factor AP-2 mediates induction by two different signal transduction pathways: protein kinase $\mathrm{C}$ and cAMP. Cell. 51:251-260.

15. Copp, R. P., and H. H. Samuels. 1989. Identification of an adenosine 3',5'-monophosphate (cAMP)-responsive region in the rat growth hormone gene: evidence for independent and synergistic effects of cAMP and thyroid hormone on gene expression. Mol. Endocrinol. 3:790-796.

16. Dana, S., and M. Karin. 1989. Induction of human growth hormone promoter activity by the adenosine $3^{\prime}, 5^{\prime}$-monophosphate pathway involves a novel response element. Mol. Endocrinol. 3:815-821.

17. Keech, C. A., and A. Gutierrez-Hartmann. 1989. Analysis of rat prolactin promoter sequences that mediate pituitary-specific and $3^{\prime}, 5^{\prime}$-cyclic adenosine monophosphate-regulated gene expression in vivo. Mol. Endocrinol. 3:832-837.

18. Wondisford, F. E., E. A. Farr, S. Radovick, H. J. Steinfelder, J. M. Moates, J. H. McClaskey, and B. D. Weintraub. 1989. Thyroid hormone inhibition of human thyrotropin $\beta$-subunit gene expression is mediated by a cis-acting element located in the first exon. J. Biol. Chem. 264:14601-14604.

19. Dignam, J. D., R. M. Lebovitz, and R. G. Roeder. 1983. Accurate transcription initiation by RNA polymerase II in a soluble extract from isolated mammalian nuclei. Nucleic Acids Res. 11:1474-1489.

20. Garner, M. M., and A. Revzin. 1981. A gel electrophoresis method for quantifying the binding of proteins to specific DNA regions: application to components of the Escherichia coli lactose operon system. Nucleic Acids Res. 9:30473060 .

21. Wondisford, F. E., S. J. Usala, G. S. DeCherney, M. Castren, S. Radovick, P. W. Gyves, J. P. Trempe, B. P. Kerfoot, V. M. Nikodem, B. J. Carter, et al. 1988. Cloning of the human thyrotropin $\beta$-subunit gene and transient expression of biologically active human thyrotropin after gene transfection. Mol. Endocrinol. 2:32-39.

22. Carr, F. E., M. A. Shupnik, J. Burnside, and W. W. Chin. 1989. Thyrotropin-releasing hormone stimulates the activity of the rat thyrotropin $\beta$-subunit gene promoter transfected into pituitary cells. Mol. Endocrinol. 3:717-724.

23. Weintraub, B. D., F. E. Wondisford, E. A. Farr, H. J. Steinfelder, S. Radovick, N. Gesundheit, P. W. Gyves, T. Taylor, and G. S. Decherney. 1989. Pre-translational and post-translational regulation of TSH synthesis in normal and neoplastic thyrotrophs. Horm. Res. (Basel). 32:22-24.

24. Hoshi, T., S. S. Garber, and R. W. Aldrich. 1988. Effect of forskolin on voltage-gated $\mathrm{K}^{+}$channels is independent of adenylate cyclase activation. Science (Wash. DC). 240:1652-1655.

25. Day, R. N., J. A. Walder, and R. A. Maurer. 1989. A protein kinase inhibitor gene reduces both basal and multihormone-stimulated prolactin gene transcription. J. Biol. Chem. 264:431-436.

26. Ingraham, H. A., S. E. Flynn, J. W. Voss, V. R. Albert, M. S. Kapiloff, L. Wilson, and M. G. Rosenfeld. 1990. The POU-specific domain of Pit-1 is essential for sequence-specific, high affinity DNA binding and DNA-dependent Pit-1Pit-1 interactions. Cell. 61:1021-1033.

27. Brent, G. A., J. W. Harney, D. D. Moore, and P. R. Larsen. 1988. Multihormonal regulation of the human, rat, and bovine growth hormone promoters: differential effects of 3 ',5'-cyclic adenosine monophosphate, thyroid hormone, and glucocorticoids. Mol. Endocrinol. 2:792-798.

28. Steinfelder, H. J., P. Hauser, Y. Nakayama, S. Radovick, J. H. McClaskey, T. Taylor, B. D. Weintraub, and F. E. Wondisford. 1991. Thyrotropin-releasing hormone regulation of human $\operatorname{TSH} \beta$ gene expression: role of the pituitary-speci- 
fic transcription factor (Pit-1/GHF-1) and potential interaction with a thyroid hormone inhibitory element. Proc. Natl. Acad. Sci. USA. 88:3130-3134.

29. Nelson, C., V. R. Albert, H. P. Eisholtz, L. E. W. Lu, and M. G. Rosenfeld. 1988. Activation of cell-specific expression of rat growth hormone and prolactin genes by a common transcription factor. Science (Wash. DC). 239:1400-1405.

30. Crenshaw, E. B., K. Kalla, D. M. Simmons, L. W. Swanson, and M. G. Rosenfeld. 1989. Cell-specific expression of the prolactin gene in transgenic mice is controlled by synergistic interactions between promoter and enhancer elements. Genes Dev. 3:959-972.

31. Li, S., E. B. Crenshaw, E. J. Rawson, D. M. Simmons, L. W. Swanson, and M. G. Rosenfeld. 1990. Dwarf locus mutants lacking three pituitary cell types result from mutations in the POU-domain gene pit-1. Nature (Lond.). 347:528533.

32. Alexander, L. M., D. J. Williamson, W. M. Wood, D. F. Gordon, E. C. Ridgway, and A. Gutierrez-Hartmann. 1990. Activation of the murine thyrotropin $\beta$-subunit promoter by $\mathrm{GH}_{4}$ rat pituitary cell-free extracts. Mol. Endocrinol. 4:1887-1896.

33. Kapiloff, M. S., Y. Farkash, M. Wegner, and M. G. Rosenfeld. 1991. Variable effects of phosphorylation of Pit-1 dictated by the DNA response element. Science (Wash. DC). 253:786-789.
34. McCormick, A., H. Brady, L. E. Theill, and M. Karin. 1990. Regulation of the pituitary-specific homeobox gene GHF 1 by cell-autonomous and environmental cues. Nature (Lond.). 345:829-832.

35. Gonzalez, G. A., and M. R. Montminy. 1989. Cyclic AMP stimulates somatostatin gene transcription by phosphorylation of CREB at serine 133. Cell. 59:675-680.

36. Milsted, A., R. P. Cox, and J. H. Nilson. 1987. Cyclic AMP regulates transcription of the genes encoding human chorionic gonadotropin with different kinetics. DNA. 6:213-219.

37. Jameson, J. L., and C. M. Lindell. 1988. Isolation and characterization of the human chorionic gonadotropin $\beta$ subunit $(\mathrm{CG} \beta)$ gene cluster: regulation of a transcriptionally active CG $\beta$ gene by cAMP. Mol. Cell. Biol. 8:5100-5107.

38. Fenstermaker, R. A., A. Milsted, J. B. Virgin, W. L. Miller, and J. H. Nilson. 1989. The transcriptional response of the human chorionic gonadotropin $\beta$-subunit gene to cAMP is cycloheximide sensitive and is mediated by cis-acting sequences different from that found in the $\alpha$-subunit gene. Mol. Endocrinol. 3:1070-1076.

39. Fuh, V. L., J. M. Burrin, and J. L. Jameson. 1989. Cyclic AMP (cAMP) effects on chorionic gene transcription and mRNA stability: labile proteins mediate basal expression whereas stable proteins mediate cAMP stimulation. Mol. Endocrinol. 3:1148-1156. 